\title{
Buitinių patogumų pokyčiai Vilniaus pirklių namuose XIX a. antrojoje pusëje
}

\author{
AELITA AMBRULEVIČIŪTÉ \\ Vilniaus universitetas, Universiteto g. 7, LT-01513 Vilnius \\ El. paštas aelita@fan.It
}

\begin{abstract}
Straipsnyje (*) nagrinèjama Vilniaus pirklių - pasiturinčių miestiečių su mažiau ribotomis finansinemis galimybėmis - buities organizavimo pokyčiai XIX a. antrojoje pusèje, susiję su naujų buitinių patogumų formų plitimu, būstų erdvės reorganizavimu.
\end{abstract}

Raktažodžiai: XIX a., pirkliai, Vilnius, buitiniai patogumai

\section{JVADAS}

Pažangesniuose Europos miestuose tvarkyti namų ūkị ir labiau rūpintis miestų sanitarine būkle pastūmèjo $1854 \mathrm{~m}$. Londoną apèmusi choleros epidemija ir $1858 \mathrm{~m}$. užgriuvęs „didysis tvaikas“ (the great stink). Šių îvykių virtinè ir Johno Snowo atradimas, paneigęs infekcinių ligų (choleros, tymų, maliarijos) plitimo oru teoriją (angl. - miasmatic theory) ir choleros plitimą susiejęs su geriamojo vandens užterštumu žalingomis bakterijomis, Europos šalių vyriausybèms, miestų administracijai tapo akstinu tvarkyti miestų aplinką, gerinti sanitarinę būklę $[63,14-19 ; 58 ; 54 ; 68]$.

Rūpinimasis Europos miestų sanitarine būkle technologijų raidos laikotarpiu inspiravo ir buitinių patogumų pokyčius: keitèsi miestiečių gyvenimo sąlygos, buities organizavimas, vidinès erdvès išplanavimas. Vakarų Europos buržuazinės visuomenès tyrëjai butų struktūros pokyčius sieja su viešosios ir privačios erdvès atskyrimu ir specializuotų kambarių (svetainès, miegamojo, valgomojo, kabineto ir kt.) paplitimu iš esmès visų socialių grupių būstuose [53-57; 64].

Buities pokyčiai, komunalinių atliekų tvarkymas, vandentiekio ir nuotakyno sistemų renovacija, naujų buitinių patogumų formų atsiradimas Vilniuje, kaip ir daugelyje XIX a. Europos miestų, siejamas su XIX a. viduriu. Šių procesų raidą Rusijos imperijos miestuose (ir Vilniuje) analizavę mokslininkai atkreipè dèmesị, kad modernūs patogumai pirmiausia buvo įrenginejjami naujai statytuose nuomojamuose namuose (доходные дома), skirtuose

(*) Straipsnis parengtas vykdant Lietuvos mokslo tarybos remiamą mokslininkų grupès iniciatyva parengtą projektą „Vilniaus pirkliai XIX amžiuje: teisinè situacija, veikla, socialinė tapatybë“. Sutarties Nr. MIP$070 / 2014$. 
vidurinei klasei. Šie namai išsiskyrè ne tik moderniais buitiniais patogumais, bet ir būsto erdvès išplanavimu [59-61; 66; 67].

Vilniuje nuomojamų namų statyba išplito XIX a. 9-ajame dešimtmetyje, tačiau buitinių patogumų pokyčių pasiturinčių miestiečių būstuose būta jau 7-ojo dešimtmečio pradžioje. Pasiturintys miestiečiai buvo skirtingų socialinių grupių atstovai. Viena jų - pirkliai, verslo elitas - XIX a. pabaigoje statėsi daug naujų namų, renovavo senus. Tai paskatino tirti pasiturinčių pirklių su mažiau ribotomis finansinėmis galimybėmis buities sąlygas. Pasirinktas objektas padejjo apžvelgti naujų buitinių patogumų formų plitimą Vilniaus gyventojų buityje, stebèti, kaip greitai jos buvo perimtos.

Straipsnio tikslas - išanalizuoti Vilniaus pirklių buities pokyčius XIX a. antrojoje pusẻje. Šiam tikslui pasiekti keliami papildomi uždaviniai: 1) nustatyti buitinių patogumų pokyčius Vilniuje ir 2) išsiaiškinti, kokios naujų patogumų formos buvo diegtos pirklių namuose.

1870 ir 1892 m. „Rusijos miestų nuostatai“ (Городовое положение) miesto dūmai pavedè prižiūrèti ir tvirtinti nuosavų pastatų statybos, renovacijos ir rekonstrukcijos darbus, kurie galèjo būti atlikti gavus Statybos komisijos leidimą ir prižiūrint miesto architektui. Ši namų savininkams nepatogi biurokratinè tvarka nūdienos tyrẻjams paliko galingą dokumentų masyvą.

Dokumentai saugomi Lietuvos valstybès istorijos archyvo Vilniaus miesto valdybos fonde (Vilniaus statybos skyrius, f. 938, ap. 4). Tai - gyvenamujų namų savininkų numatytų renovacijos / statybos darbų prašymai, namų rekonstrukcijų brèžiniai, pastatų planai, namų savininkų, kuriems buvo leista atlikti pastatų renovacijos darbus, sąrašai, nekilnojamojo turto vertinimo komisijos sudaryti pastatų vidaus aprašymai, miesto ūkio sanitarijos komisijos ataskaitos, dūmos posèdžių protokolai ir kita.

Šie dokumentai leido pasekti Vilniaus gyventojų buities pokyčius, analizuoti Vilniaus pirklių gyvenimo sąlygas, jų būstų išplanavimą, numatyti, kokios erdvės galèjo būti ịrengtos jų namuose, nustatyti, kokie ir kuriais metais įrengti modernūs buitiniai patogumai (vandentiekis, nuotakynas, klozetai, vonios). Šiuos duomenis papildo XIX a. periodinèje spaudoje aptikti būstų nuomos skelbimai, padeję susidaryti bendresnį buitinių patogumų pokyčių vaizdą mieste, analizuoti ịvairių socialinių sluoksnių gyvenimo ir buities sąlygas, stebèti, kaip buvo organizuojama pirklių buitis.

\section{BUITIES ORGANIZAVIMO POKYČIAI}

XIX a. antrojoje puseje pastebimai keitèsi Vilniaus vaizdas, jo užstatymas, formavosi nauji kvartalai, mažèjo didelių, prabangių baroko stiliaus rūmų, rezidencijų poreikis, augo nuomojamų namų (доходныл дома) paklausa. Pasiturintys miestiečiai, vidurinè klasė, kylanti miesto buržuazija statėsi arba nuomojamus namus, arba mažesnes rezidencijas. Didelių rezidencijų poreikio mažejimą architektūros istorikè Nijolè Lukšionytė-Tolvaišienė sieja su vietinių didikų politinès galios smukimu, finansinių galimybių mažejjimu ir smarkiai pasikeitusiu rezidencijų fundatorių sluoksniu. Autore pažymi, kad daugelį naujų rezidencijų statėsi krikščioniškų konfesijų gyventojai, o pirkliai žydai statė daugiau didesnių namų su įvairaus dydžio butais $[61,93,137]$.

Pažymėtina, kad pirkliai rinkosi namus atsižvelgdami ir ị verslo specifiką: prekybai, komercijai, bankų kontoroms ir kitoms įmonėms steigti labiau tiko triukšmingos, su dideliais žmonių srautais centrinès miesto gatvès. Todèl XIX a. pirmojoje pusejje pirkliams buvo svarbu įsigyti namą miesto centre. Be to, gyvenimas miesto centre, o dargi buvusioje didiko rezidencijoje, žymèjo pirklio materialią padètí, verslo sèkmę, kèlè statusą. 
Duomenys rodo, kad XIX a. pirmojoje pusejje beveik visi pirkliai krikščionys patalpas verslui nuomojosi miesto centre. Tiesa, $1862 \mathrm{~m}$. iš 36 pirklių krikščionių nuosavus namus miesto centre turèjo tik keturi pirkliai: Fiorentiniai (194, 195 posesijų namai, neišliko) ir Genrichas Šmitas (197 posesijos namas) - Didžiosios gatvès ir Švarco skersgatvio kampiniai namai; Poznanskai - Vokiečių gatvejje (296 posesijos namas - buvęs dabartinio Šiuolaikinio meno centro pastato vietoje), Vincenta Zavadzka - Bernardinų skg. (149 posesijos namas). Kampinị Didžiosios ir Stiklių g. namą (greičiausiai Didžioji g. 17/1) iki 9-ojo dešimtmečio vidurio ịsigijo Petras Gruževskis, iki tol patalpas prekybai nuomojęs Didžiojoje g., 201 posesijos name (dab. - Didžioji g. 11) [1, 57v-59; 12, 20v-21; 11, 7v].

Žydams iki $1861 \mathrm{~m}$. ̣̇statymo buvo draudžiama gyventi ir prekiauti centrinèse miesto gatvėse (Aušros vartų, Didžiojoje, Pilies, Trakų, Domininkonų, Šv. Jonų), išskyrus Vokiečių gatvę, tad jie apgyvendino šalutines miesto centro gatves, o Vokiečių gatvè tapo pirklių žydų traukos centru.

XIX a. pirmojoje pusejje pirkliai žydai ịsigijo 13 iš 32 buvusių gatvejje namų. Tačiau ir Didžiojoje gatvejje iki $1861 \mathrm{~m}$., matyt, labiausiai nebijantys rizikuoti pirkliai žydai turejo kelis namus: 1825-1857 m. kampinis Latako ir Didžiosios gatvių namas (103 posesija) buvo Joselio Jogicheso nuosavybè [52, 105-106, 128], nuo 1828 m. kampinio Vokiečių ir Didžiosios gatvių namo savininkas buvo pirklys Zelmanas Prenskis [52, 85-86, 94, 108], 1830 m. kampinio Pilies ir Barboros Radvilaitès gatvių namo (154 posesija) savininku nurodytas pirklys Morduchas Kliačko [52, 117], o Pilies gatvès 109 posesijos namo savininku 1852 m. - pirklys Aizikas Mackevičius [52, 145], 1853-1854 m. - Chaimas Gurvičius [52, 99]. Tarp 1854 ir 1857 m. kampinị Dominikonų ir Vokiečių gatvių namą (411 posesija) įsigijo Tauba ir Aronas Lebensonai, įkurdinę viešbutį „Europa“ [52, 134]; panašiu metu kampini Savičiaus ir Didžiosios gatvių namą įsigijęs persikrikštijusio pirmosios gildijos pirklio Saliamono Geimano sūnus Aleksandras jame ịkurdino banko kontorą [52, 86-87].

XIX a. 8-9-uoju dešimtmečiais situacija keitèsi ir pagrindinès miesto arterijos (Aušros vartų, Didžioji, Pilies ir Trakų, Domininkonų, Šv. Jonų bei Vokiečių gatvès) virto komerciniu ir administraciniu centru. Čia nemažai namų ísigijo pirkliai, daugelio namų patalpos buvo nuomojamos komercijai. Senoji miesto teritorijos dalis išlaikè komercinio ir administracinio centro vaidmenị ir XIX a. pabaigoje, tačiau plečiantis miestui, tiesiant naujas plačias gatves keitèsi rajonų prestižas.

Apie 9-ojo dešimtmečio pabaigą formavosi modernūs su komfortabiliais namais miesto rajonai: „Geriausia, nelabai tankiai apgyvendinta miesto dalimi, kurioje gyveno pasiturintys žmonès, buvo laikoma šiaurès-vakarinè miesto dalis (Gedimino pr., dalis Vilniaus g. ir Antakalnis), kurioje kiekvienais metais statomi nauji namai, vienas už kitą patrauklesni butų apdaila ir patogumais, vis labiau priminė sostinės butus su koridorių sistema, vaterklozetais, privažiavimu iš gatvès ir pan." $[49,116]$.

Šiuolaikinè istoriografija pažymi, kad XIX a. antrojoje puseje Vilnius smarkiai plètèsi i plotị: išaugo keli priemiesčiai, kuriuose iki to laiko buvo miesto gyventojų daržai arba mediniai nameliai. Vakarinè miesto dalis pradejo augti XIX a. viduryje (Gedimino pr., Lukiškių, Žvėryno priemiesčiai). Pietvakarineje miesto dalyje (Vingrių skg., Pylimo, Raugyklos, Naugarduko ir kitos gatvès iki Smolensko gatvės), kuri gavo Naujamiesčio (Новыı̆ город) vardą, XIX a. pabaigoje išaugo labai daug naujų kvartalų, gatvių. Išsiplètė pietinè miesto dalis ties geležinkeliu, o už jo išaugo Naujojo Pasaulio (Новыıй Cвеm) priemiestis [59, 290-291]. 
XIX a. pabaigoje pirkliai „senojo“ miesto dalies neapleido, tačiau kèlèsi ir ì naujai plečiamus modernius Vilniaus rajonus: Naujamiestị, Gedimino pr., Vilniaus, Sodų, Gèlių, Pylimo, J. Basanavičiaus ir kitas naujai formuojamas ar pertvarkomas gatves.

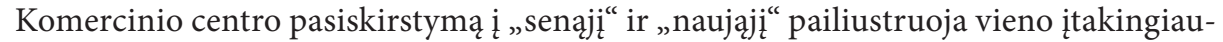
sių ir turtingiausių Vilniaus pirklių, bankininko, miesto tarybos nario, šokolado fabriko „Viktorija“" steigejo, kelių namų Vilniuje savininko Izraelio Bunimovičiaus raštas, $1901 \mathrm{~m}$. pateiktas Vilniaus miesto valdybos İvertinimo komisijai. Prašydamas perskaičiuoti nepelnytai didelị būsto mokestị I. Bunimovičius rašè: „<..> daugelis prekybininkų perkèlè verslą ị Didžiąją gatvę, ị Šv. Jurgio prospektą ir kitas naujai atidarytas gatves, o Vokiečių gatvès namuose lieka neišnuomotų patalpų. Mano name šiuo metu irgi yra kelios neužimtos patalpos“ $[31,19-9 v]$.

Pirklių siekius užimti reprezentatyvius, patogius gyvenimui ir verslui naujai formuojamus rajonus sąlygojo ir galimybė tuščiuose sklypuose statyti didelius modernius nuomojamus namus. Jų statyba Rusijos imperijoje išplito XIX a. antrojoje pusejje. Vilniuje nuomojamų namų statybos bumas prasidejo apie XIX a. 9-ojo dešimtmečio vidurị, bet dauguma jų pastatyta dviem paskutiniais dešimtmečiais, ypač sparčiai statyta 18961901 metais $[61,146]$.

Remdamasis $1875 \mathrm{~m}$. surašymo statistika, nežinomas autorius pateikè štai tokius duomenis: 1875 m. Vilniuje buvo 12787 butų su 27500 kambariais. Viename name vidutiniškai gyveno 50 gyventojų, t. y. butai buvo apgyvendinti tankiau nei Maskvoje, Londone, Karaliaučiuje, Odesoje. Vidutiniškai viename bute gyveno septyni žmonès. 1875 m. vieno kambario butų buvo 47 proc., dviejų kambarių - 25 proc. (palyginimui: Sankt Peterburge - atitinkamai 19 ir 17 proc.) $[50,15]$.

1913 m. duomenimis, Vilniuje buvo 35742 butai: vieno ir dviejų kambarių - 25529 (71,4 proc.), trijų-penkių - 8897 (24,9 proc.), šešių ir daugiau - 1316 (3,7 proc.). Laikraščio Przegląd Wileński korespondentas $1913 \mathrm{~m}$. daro išvadą, kad „Vilnius buvo mažų būstų miestas, apgyvendintas neturtingų žmonių“ $[48,3]$.

Vadovaujantis Rusijos dailètyros daktaro, Rusijos imperijos architektūros istorijos specialisto A. Punino atliktu XIX a. vidurio Sankt Peterburgo architektūros tyrimu, galima teigti, kad Rusijos imperijos miestų raidai būdingi pagrindiniai architektūros principai buvo taikomi ir Vilniui: „korpuse nuo gatvès paprastai būdavo įrenginejjami dideli, daug kambarių turintys butai, skirti pasiturintiems gyventojams; neretai vieną geriausių butų užimdavo namo savininko šeima. Dideli butai dažniausiai turèdavo du ịejimus - paradinị iš gatvès ir papildomą (черныц̆), išeinantị ị kiemą. Komfortabiliai ịrengtuose namuose paradinès laiptinès būdavo šildomos. Papildomos laiptinès pritaikytos malkoms atnešti, jomis naudodavosi tarnai ir aptarnaujantysis personalas. Šalia išejimo i papildomą laiptinę būdavo virtuvès, tarnų kambariai, tualetai. Taigi dvi laiptinès dalijo butus ị ponų ir ùkinę zonas. Pažymėtina, kad didesniuose butuose ponų zona dar dalijama ị paradinius kambarius, kur vykdavo svečių prièmimai, ir ị privačias patalpas. Kiemo fligeliai turèdavo vieną laiptinę. Čia telkèsi nedideli ir pigūs butai. Virtuvè, sanitarinis mazgas, sandèliukas tokiuose butuose būdavo šalia įejjimo“" [67].

Tuos pačius universalius būstų išplanavimo principus XIX a. pabaigoje pažymi ir Lietuvos architektūros istorikė N. Lukšionytė-Tolvaišienè: „Vidutinio didumo Vilniaus butuose kambariai nebeturèjo paradinio pobūdžio, jie izoliuoti ir sujungti koridoriais, o virtuvès, podèliai, sanitariniai mazgai sugrupuoti prie pagalbinių laiptų - per juos išeinama ị kiemą, kuriame stovėdavo „službos“ su ratine, sargo butu ir kiti ùkiniai pastatai 
(malkinè, sandèliai, lauko išvietè)“ [61, 147]. Lietuvos architektūros istorijoje rašoma, kad „XIX a. butų suplanavimas pradžioje perèmè tradicinę rezidencinių rūmų struktūrą. Buvo daromi erdvūs vestibiuliai, paradiniai kambariai ijungti i anfiladas. Palaipsniui buto schema paprastèjo: apsiribota mažu prieangiu, izoliuotus kambarius pradèta jungti koridoriais <...> $>$ i gatvę paprastai orientuota svetainè, valgomasis, kabinetas, $\mathfrak{i}$ kiemą - miegamieji, virtuvès, sanitariniai mazgai. Buitinès patalpos būdavo grupuojamos prie šalutinių laiptų - jais būdavo nusileidžiama ị kiemą, kuriame stovejjo malkinès ir pagalbiniai trobesiai $($ служба)“ $[60,131]$.

Koks pagal XIX a. pabaigos - XX a. pradžios terminiją būstas buvo prabangus, su visais arba naujais patogumais? Atsakymą randame 1899 ir 1904 m. būsto Vilniaus ir Islandijos gatvių kampiniame name nuomos skelbimuose. 1899 m. rašyta: „nuomojami ропц butai (барская квартира) su visais patogumais, voniomis, klozetais, dujiniu apšvietimu, sandèliais, karietinemis (каретными сараями), ledaine ir rūsiais, kaina [metams] nuo 300 iki 1300 rublių“ [35, 4]. 1904 m. kiek pakoreguotas skelbimas praneša: „nuomojamas aštuonių-devynių kambarių ponų butas trečiajame aukšte su langais ir balkonu ị dvi puses, vandentiekiu, vonia, klozetu ir dujinių apšvietimu, nuomos kaina metams - 1 100-1 200 rublių“ $[44,4]$.

Kitas skelbimuose akcentuotas būsto privalumas - jo aukštas. Butai antrajame (turbūt ir trečiajame) aukšte buvo brangesni nei pirmajame ar paskutiniajame (dažniausiai ketvirtajame) aukštuose: Totorių ir Odminių gatvių kampiniame K. Geco name keturių kambarių buto antrajame aukšte nuomos kaina siekè 320 rb per metus, keturių kambarių ketvirtajame aukšte - 180 rb, trijų kambarių pirmajame aukšte - 150 rublių $[44,4]$. Greičiausiai aukšto kainą lèmė ne vien būsto plotis. Saugumas ir patogumas irgi buvo svarbūs būsto vertinimo kriterijai. Pirmojo aukšto gyventojai buvo mažiau apsaugoti nuo vagių, chuliganų išdaigų, o paskutiniojo turèjo dèti daugiau pastangų pakilti ị aukštą, atsinešti malkų arba anglies, išnešti buitines atliekas, šlaką ir pan.

Taigi susipažinę su XIX a. antrosios pusès gyvenamojo fondo specifika Vilniuje, paanalizuokime, kiek ir kokias komunalines naujoves įrengè pirkliai, kokio dydžio butus rinkosi gyventi, kiek buvo imlūs naujovèms.

\section{PIRKLIŲ BŨSTŲ STRUKTŪRA IR NAUJŲ BUITINIŲ PATOGUMŲ FORMŲ PLĖTRA}

Šiam tyrimui atlikti pirmiausia teko lokalizuoti pirklių gyvenamąją vietą - nustatyti namą ir butą. Paprastai šaltiniai leido nustatyti daugiausia namo(-ų) adresą(-us). Butą nustatyti gana sudėtinga. Pavyzdžiui, antrosios gildijos pirklys Karlas Akenas, paskirtas Imperatoriškojo Vokietijos konsulato Šiaurès vakarų krašte Vilniaus, Kauno, Gardino ir Suvalkų gubernijoms agentu, nuo $1889 \mathrm{~m}$. buvo ịkurdinęs parduotuvę Vokiečiu gatvėje, 372 posesijos name $[17,129 \mathrm{v}-130] .1901 \mathrm{~m}$. vieno kambario butą šio namo antrajame aukšte nuomojo Vilhelmas Akenas [29, 20v], o Karlas Akenas 1903 m. gyveno J. Basanavičiaus g.14 name (pagal tuometinę numeraciją) [47, 25]. Tačiau kur pirklys gyveno iki tol, kuriais metais apsigyveno nurodytu adresu ir kaip ilgai ten gyveno, - neaišku.

Pirklio Leibos Zalkindo atveju galima kalbèti apie keturis jam priklausiusius namus (13, 271, 272 ir 273 posesijos). Žinant, kad 271, 272 ir 273 posesijos namai (dab. - Didžioji g. 33) turèjo komercinę paskirtị, galima spėti, jog pirklys su šeima gyveno kampiniame Aušros vartų ir Etmonų gatvių 13 posesijos name. Tačiau keturių aukštų name buvo daugiau nei vienas butas [52, 3v-4], ir Leiba Zalkindas galejo gyventi bet kuriame iš jų. 
Taigi, net žinant pirklio gyvenamąji namą, ne visuomet galima nustatyti butą, o pirklio Mejerio Gordono atveju (M. Gordonas turejo mažiausiai tris namus) gana sudètinga išsiaiškinti net namą, kuriame pirklys gyveno.

Žinoma, kad M. Gordonui priklausė du namai Subačiaus gatvejje: 1862-1888 m. 26 posesijos namas (Subačiaus g. 9), 1864-1876 m. - 1979 posesijos namas ir 18831939 m. - 384 posesijos namas Vokiečių gatvèje (buvęs antras namas nuo Didžiosios ir Vokiečių g. kampo). Vilniaus miesto $1864 \mathrm{~m}$. sudarytoje rodyklèje nurodyti pirkliui priklausę du namai Subačiaus gatvejje - Nr. 3 ir 8 [51, 63], 1875 ir 1876 m. vertinimo komisijos aprašyti tie patys $M$. Gordono namai $[3,16 ; 4,26]$, o 26 posesijos namo $1888 \mathrm{~m}$. rekonstrukcijos brěžinyje savininkais vis dar nurodyti Mejeris ir Dina Gordonai [16, 3].

Istoriografijoje minima, kad šis namas M. Gordono nuosavybe buvo nuo $1862 \mathrm{~m}$. iki amžiaus pabaigos: $1868 \mathrm{~m}$. name pirklys įkūrè sinagogą, o XIX a. pabaigoje - ir Pagrindinę dvasinę maldos valdybą [65, 482]. Taip pat nustatyta, kad tarp 1875 ir $1883 \mathrm{~m}$. M. Gordonas įsigijo 384 posesijos namą Vokiečių gatvejje [9], kuriame net nuo $1825 \mathrm{~m}$. Gordonų šeima nuomojo patalpas audinių parduotuvei $[52,96]$. Šis namas Gordonams priklausè iki 1939 metų [21, 79; 23, 31v-32; 27, 4v-5; 30, 8; 65, 112]. Klausimas - kuriame iš namų galejo gyventi pirklys?

Žinant, kad namų savininkai, juolab aukštesnị socialinị statusą pasiekę pirkliai, rinkosi geriausius butus name, ir prisiminus, kad pagal XIX a. tradiciją prestižiniais gyventi laikyti antras ir trečias aukštai, paanalizuokime abiejų M. Gordono namų antrųjų aukštų aprašymus: abu namai Subačiaus gatveje buvo dviejų aukštų, abu panašaus ploto (26 posesijos namo antrajame aukšte buvo 12 kambarių, 21 durys ir 29 langai, 13 krosnių, trys virtuvès ir trys virtuvinès krosnys [3, 16]; 1979 posesijos namo antrajame aukšte buvo 15 kambarių, 28 durys ir 26 langai, aštuonios krosnys, dvi virtuvès ir dvi virtuvinès krosnys $[4,26]$ ).

Virtuvès patalpų ir virtuvinių krosnių skaičius leidžia daryti prielaidą, kad 26 posesijos namo antrajame aukšte buvo trys butai (tai rodo ir trys priemenès). 1979 posesijos namo antrajame aukšte dvi virtuvès ir dvi virtuvinès krosnys leidžia teigti, kad čia greičiausiai buvo įrengti du dideli butai (galbūt septynių ir aštuonių arba šešių ir devynių kambarių), o keturios priemenès rodo du galimus (paradini ir juodąjį) kiekvieno buto ¡̇ejimus. Be to, parketu iškloti keturi kambariai vis dèlto gali būti ženklas, kad sèkmingai plètodamas verslą ir $1875 \mathrm{~m}$. pakilęs ị pirmąją gildiją $[15,54806]$ pirklys greičiausiai rinkosi puošnesnị, komfortiškesnị būstą.

„Praverti“ kito M. Gordono buto duris padeda $1901 \mathrm{~m}$. Vokiečių gatvès turto vertinimo komisijos žiniaraštis, kuriame labai išsamiai aprašyta kiekvieno namo patalpų nuomos paskirtis, kiekviename aukšte išsidèsčiusių butų kambarių skaičius, kuriame aukšte, kelių kambarių bute gyveno namo savininkas ir nuomininkai. Taip sužinome, kad $1901 \mathrm{~m}$. Mejeris Gordonas gyveno 384 posesijos namo antrajame aukšte keturių kambarių bute, o vienas iš jo sūnų Nochimas gyveno gretimame šešių kambarių bute [30, 9v].

$\mathrm{XX}$ a. pradžios pasiturinčio miestiečio, žinomo ir gerbiamo mieste visuomeninio veikejjo, labdaros fondų rèmėjo, pirmosios gildijos pirklio gyvenamąją erdvę galime rekonstruoti pasitelkę šiuolaikinius tyrimus. Daugelis autorių pripažista, kad butų erdvę pradèta planuoti taip, kad atsirastų vietos specializuotiems kambariams. Jų skirtingos funkcijos (svetainè, miegamasis, valgomasis, kabinetas, virtuvé, vaikų, tarnų, pasilinksminimų kambariai ir kita) rodo esminius pokyčius vidurinès klasès gyvenime - poreiki turèti atskiras erdves, t. y. šeimos narių ir tarnų viešą ir privačią erdves $[53,21 ; 55,120-133$; $56,127-131 ; 57,57 ; 64,127-129]$. 
Vadovaujantis šiais tyrimais galima teigti, kad svetainè (kitaip - paradinis kambarys, salonas, priimamasis) atliko ne tik priimamojo, salono funkciją. Ji tapdavo savotiška „užkarda“, trukdanti ne šeimos nariui patekti ị privačias šeimos narių erdves. Neretai paradinis kambarys su parketu, puošniu interjeru, išstatytais porceliano indais, iškabintais veidrodžiais slèpé labai kuklią namo savininko buitį. Toliau pagal svarbą rikiavosi miegamasis, kabinetas, virtuvè, kuri galejo būti sujungta su tarnų kambariu, neretai čia miegodavo ir vaikai, vaikų kambarys ir valgomasis, pagal galimybę ar poreiki - „moteriškasis" kambarys, pasilinksminimų kambarys ir kita.

Pagal gyvenimo ir veiklos būdą pirkliams buvo privalu turèti kabinetą ir svetainę. Kabinete šeimos galva netrukdomas galejjo apsvarstyti biznio reikalus, suvesti i̇monès balansą, organizuoti privatų susitikimą su verslo partneriais, o svetainejje - priimti svarbius, „reikalingus“ žmones, verslo partnerius, rengti kviestinius pietus, iškilmingas vakarienes, pobūvius.

Tikètina, kad 1901 m. aštuntąj dešimtmetị perkopęs Mejeris Gordonas gyveno su žmona ir veikiausiai turèjo tarnaitę. Jo keturių kambarių bute turbūt buvo ịrengta svetainè, kabinetas, miegamasis ir virtuvè. I šeštąji dešimtmetị ižzengusio pirklio sūnaus Nochimo šešių kambarių bute galèjo būti numatytos papildomos erdvès (valgomasis ir tarnų kambarys). Aišku, turèdamas, pavyzdžiui, 1897-1898 m. per $10000 \mathrm{rb}$ metinio pelno [26, 45v-46; 27, 37v-38], M. Gordonas galejo apsigyventi ir didesnio ploto bute, bet mums nèra žinomi motyvai, paskatinę pirklị rinktis butą su mažesniu kambarių skaičiumi.

Paanalizuokime ir kitų Vokiečių gatveje gyvenusių pirklių užimamų būstų kambarių skaičių. 1901 m. turto vertinimo komisijos žiniaraščio duomenimis, komercinę paskirtị pelniusioje Vokiečių gatvejje, kur kiekviename name buvo nuo kelių iki kelių dešimčių komercinès paskirties įmonių, nuosavus namus turejjo jau 18 pirklių, bet gyveno tik trys namų savininkų šeimos: minėti pirkliai Gordonai gyveno nuosavo namo (384 posesija) antrajame aukšte keturių ir šešių kambarių butuose [30, 9v], Šlioma Nemzeris - nuosavame trijų kambarių bute eksdivizinio namo (379 posesija) ketvirtajame aukšte [30,60], pirkliai Smolenskiai gyveno nuosavo namo (313 posesija) antrajame aukšte, keturių kambarių bute $[29,44 \mathrm{v}]$.

Dar keturi pirkliai nuomojo ir komercinès paskirties patalpas, ir butus: 378 posesijos name Vulfas Joselsonas pirmajame aukšte nuomojo tris kambarius parduotuvei (nuomos kaina siekė 500 rb per metus) ir antrajame aukšte - keturių kambarių butą (nuoma - 300 rb per metus) [30, 71v-72]; pirklys Psachijus Zilberštrumas 311 posesijos name nuomojo dviejų kambarių patalpas parduotuvei antrajame aukšte ir trijų kambarių butą trečiajame aukšte (650 rb per metus) [29, 48v]; pirkliai Olkinai pusrūsyje už $1875 \mathrm{rb}$ per metus nuomojo devynių kambarių patalpas 374 posesijos name, kuriose buvo įrengta parduotuvè, sandèlis ir butas, o trečiajame to paties namo aukšte nuomojo penkių kambarių butą už 425 rb per metus [29, 12v]; pirklio Karlo Akeno giminaitis Vilhelmas Akenas nuomojo vieno kambario butą 374 posesijos name antrajame aukšte (70 rb per metus) $[29,20 v]$. O štai pirklių brolių Ševelio, Chaimo ir Pereco Cholemų 1898 m. Vytenio gatvèje suprojektuotame trijų aukštų name su pusrūsiu numatyti aštuoni standartizuoti šešių kambarių butai po du kiekviename aukšte su priemene, virtuve, vonia, tualetu ir dviem iejejimais (paradiniu ir papildomu) leidžia teigti, kad broliai gyveno šešių kambarių moderniai įrengtuose ir modernaus išplanavimo (butų plane akivaizdžiai matyti atskirtos ponų ir ūkinè erdvès, izoliuoti kambariai) butuose $[28,3]$. 
Šie atvejai rodo, kad tarp pirklių populiariausi buvo keturių-šešių kambarių butai. Turimais duomenimis, Vilniuje, kaip jau minèta, vyravo vieno-dviejų kambarių nebrangūs butai, o trijų-penkių kambarių vidurinei klasei skirti butai sudarė tik ketvirtadali gyvenamojo fondo butų, šešių ir daugiau kambarių butų buvo vos keturi procentai $[48,3]$.

Jau minètas M. Gordonas, 1898 m. turèjęs per 10000 rb pelno, rinkosi keturių kambarių butą, P. Zilberštrumas, kurio metinis pelnas $1897 \mathrm{~m}$. padidèjo iki $15000 \mathrm{rb}$ [26, 57v$58 ; 27,54 \mathrm{v}-55]$, rinkosi trijų kambarių butą, o bene tris kartus mažesnị pelną turintys pirkliai Olkinai (1898 m. pelnas sieke $3600 \mathrm{rb}$ [27, 95v-96]) rinkosi penkių kambarių butą - galbūt todèl, kad ši šeima buvo labai didelè.

Pateikti pavyzdžiai rodo, kad ne visada galima susieti pirklių pajamas su pasirenkamu buto plotu. Tačiau ir nuneigti negalima, kad pirklių pajamos neturèjo ịtakos buto dydžio pasirinkimui. Vilniuje buvo labai turtingų pirklių, kurie statėi ir šeimos rezidencijas.

Turbūt vieną stambiausių XIX a. pabaigos - XX a. pradžios rezidencijų (dab. - Kultūros ministerijos pastatas J. Basanavičiaus g. 5) 1900 m. buvo pasistatydinęs I. Bunimovičius. Jam priklausė dar trys namai dabartiniame J. Basanavičiaus gatvès 19 sklype [61, 162] ir du namai Vokiečiu gatvẻje (382 posesija (buvęs Vokiečių ir Mèsinių g. kampinis namas) ir 296 posesijos namas), kurių pirmi aukštai buvo nuomojami komercinėms įmonèms, o viršutiniai - butams $[22,4 \mathrm{v}-5 ; 23,27,35 ; 24,45 \mathrm{v}, 48 \mathrm{v} ; 30,17-38]$.

I. Bunimovičiaus dukros prisiminimuose rašyta, kad iš prigimties turèjęs rafinuotą skonị pirklys atitinkamai įrengè savo rezidenciją, kurioje buvo rengiami kviestiniai vakarai [62]. N. Lukšionytė-Tolvaišienè nurodè, kad „vientisa fasado kompozicija ir erdviomis prabangiai dekoruotomis patalpomis išsiskiria „Viktorijos“ fabriko savininko Bunimovičiaus fasadas“ $[61,153]$.

Rezidencija turejjo nuosavą įvažiavimą, čia buvo vyno rūsys, prabangus kabinetas, apkaltas ąžuolinèmis plokštėmis [62]. Tikètina, kad didžiulè rezidencijos svetainė (kurioje buvo rengiami kviestiniai vakarai [62]), kaip ir „Viktorijos“ parduotuvès (Gedimino pr. 2) interjeras, „buvo labai profesionaliai sukurtas, sekant šiaurietišku nacionaliniu romantiniu modernu: prekystaliai, spintos, krosnys, židinys su laikrodžiu ir kita smulkesnè įranga pasižymi stiliaus vientisumu“ $[61,71]$.

Pirklio kabinetas galèjo būti neobaroko stiliaus. Puošnių lipdinių dekoras derèjo prie ąžuolinėmis plokštėmis apkaltų sienų, o, tikètina, pirklio įsigytas ąžuolinis rašomasis stalas su rakinamais stalčiais, apmuštas žalia gelumbe, galèjo îpareigoti îsigyti „Decadence stiliaus užsieninę lempą" [40, 4; 45,4] ir kitus rašomųjų reikmenų atributus (bronzinị prespapjè, raudonmedžio korpuso rašalinę ir Abelio Kapstromo parduotuvèje igytą „tikrą amerikietišką spausdinimo mašinèlę 'Densmor'“ $[37,4])$. Persiškas kilimas, odinè sofa su veidrodžiu virš atlošo, rakinamas sekreteras, kavos stalelis, knygų spintos, įrèmintos nuotraukos, keletas bronzinių (galbūt porceliano) statulèlių ant židinio taip pat galèjo puošti I. Bunimovičiaus kabineto interjerą.

Ilgainiui turtai pirkliams tapo priemone iškilti visuomenejje, investicija, teikiančia galimybę siekti išsilavinimo ir pakilti iki aukštuomenès ne tik materialiąja padètimi, bet ir manieromis, tradicijomis, apranga. Nors materialinio turto ir socialinio statuso siekiu motyvuojama pirklija ne visada sèkmingai perimdavo aukštuomenès gyvenimo būdą, turtai leido šiam sluoksniui atrodyti ne prasčiau, neretai - prabangiau už bajorus.

Lenktyniaudama su miesto aristokratija pirklija turejo perimti ir palaikyti jos papročius. Tačiau pirkliai ne tik perimdavo pastarosios gyvenimo manierą, bet ir kūrè savitą, adaptuotą jų poreikiams ir skoniui, stilių. Nuolat „ieškodami“ naujų prekių ar paslaugų, 
užtikrinančių verslo sėkmę, pirkliai turẻjo sekti naujausius Vakarų industrijos atradimus, stebèti mados tendencijų pokyčius rinkoje.

Kiek pirkliai sekė vakarietiško pasaulio naujoves, kiek buvo pažinę paskutines mados tendencijas, vadinasi - kiek buvo imlūs naujovèms, galima matyti analizuojant Vilniaus pirklių parduotuvių asortimentą pagal reklaminius skelbimus spaudoje. Skelbimai rodo, kad ị Vilnių pirkliai pargabendavo madingų vakarietiškų prekių, naujų, vietos rinkoje nežinomų gaminių. Jie siūle klientams „prestižines“ prekes, formuodami tam tikras mados tendencijas ir gyventojų skonị, tačiau ir patys galejo tapti prestižo - pagrindinio socialinès mitologijos vertinimo $[69,17]$ - „aukomis“.

Tikètina, kad, prekiaudamas „nauju būdu dažytu“ linoleumu, kurio dèka raštas neišsitrindavęs ilgą laiką, ir „naujausių raštų“ tapetais, kilimais, takeliais [37, 4], Karlas Akenas visa tai naudojo ir savo namų interjerui, o Petras Gruževskis galejo dekoruoti sienas jo paties prekiautais „plaunamais tapetais iš JAV“ $[38,4]$.

Taip pat tikètina, kad pirkliai Broido, prekiavę rusiškais ir prancūziškais tapetais, vandens vamzdžiais ir klozetų reikmenimis, ąžuoliniu parketu, bordiūrais, bagetais, rozetèmis ir tuo metu labai populiariais japoniškais menkniekiais $[36,4 ; 39,4 ; 42,4 ; 46,4]$, savo buto grindis išklojo ąžuoliniu parketu, sienas dekoravo veikiausiai prancūziškais (labiau prestižiniais) tapetais, lubas - atvežtais gipso lipdiniais, o etažerejje galèjo būti išstatyta japoniškų menkniekių kolekcija. Ir jau tikrai klozetais ir vamzdžiais prekiavę pirkliai namuose turejo įrengtą klozetą ir vandentiekį.

Brolių Cholemų namo statybai greičiausiai buvo naudotos jų pačių prekiaujamos geležinès sijos, bėgiai, stogui dengti - skardos lapai „Sibiro ir užsienio fabrikų“, vandentiekiui ir nuotakynui ịrengti - geležiniai ir ketaus vamzdžiai ir kita [41, 4]. Ir, aišku, įsirengę modernius sanitarinius mazgus kiekviename savo namo bute, broliai Cholemai užsakè populiarius angliškus porceliano klozetus „Tornado“, „Unitas“ arba „Valiant“ [66, 54-55] ir porcelianines vonias $[43,4]$.

Analizuojant Vilniaus pirkliams priklausančių pastatų vidinę struktūrą galima matyti, kad aptiktų namų aprašymuose langai buvo įstiklinti plonais pigesniais stiklais (полубелье стекла), rèmai dažyti balta spalva, grindys paprastai medinès, rečiau - dalis kambarių klota parketu, lubos - taip pat iš lentų, retais atvejais - tinkuotos (деревянные оштукатурены) $[2,4,16 ; 5,13 ; 6,13]$. Visi namai turèjo anais laikais iprastą krosnių šildymą, virtuvines krosnis, kai kurių namų rūsiuose įrengtos ledainès, kai kurie savininkai kiemuose turèjo įsirengę privačius vandens šulinius, o Parčevskio namo sklype (Jogailos g. 9 ir 11) pastatyta arklidè-ratinè, skalbykla ir bokštas, kuriame įrengtas vandens siurblys. Kadangi sklypo nesiekè senasis miesto vandentiekis, savininkas namus aprūpino vandeniu iš artezinio šulinio [61, 152].

Tačiau tualetą su įrengta „vaterklozetų“ sistema, vandentiekį, nuotakyną namo viduje buvo ịsirengę ne visi pirkliai ir ne visuose namuose. Turbūt ir XX a. pradžioje buitiniai patogumai neretai būdavo už buto, net - namo ribų.

Vonios kambariai interjerų planuose dažniau žymèti XIX a. pabaigoje. Išvietės (отхожие места) iki XIX a. vidurio paprastai būdavo įrengtos atskirame kiemo pastate, bet nuo 7-ojo dešimtmečio randame pastatų planus su patalpomis tualetams namo viduje. Antai pirklio Borucho Ryndziunsko namo (Jogailos g. ir Gedimino pr. kampas) $1860 \mathrm{~m}$. rekonstrukcijos brèžinyje iš kiemo pusès nurodytos trys prie namo primūrytos sanitarinių mazgų iškyšos, kurių, pasak N. Lukšionytės-Tolvaišienès, anksčiau namo viduje nebūdavo $[61,138]$. Namo viduje įrengtą tualetą, ị kurị vedè du įejimai: iš kiemo pusès ir iš bendrojo 
koridoriaus pačiame name, galima matyti ir pirklio Leibos Rapoporto namo Vilniaus gatveje plane $[61,139]$, ir iš pirklių šeimos kilusio majoro Stepono Poznanskio $1886 \mathrm{~m}$. namo plane (Paménkalnio g. 2) [61, 141].

Galbūt nesandari tualetų sistema daugeli namų savininkų atgrasino rengti tualetus name. Pavyzdžiui, nei $1874 \mathrm{~m}$. pirklio Meilacho Kenigsbergo namo plane $[61,139]$, nei pirklio A. Maizelio $1880 \mathrm{~m}$. namo plane tualetai nepažymèti [61, 141]. Netgi vienas turtingiausių Vilniaus žmonių bankininkas Juozapas Montvila 1889 m. Gedimino pr. 857 posesijos namo kieme, ūkinio pastato ir arklidès kairiajame šone, ịrengè šešių vietų nešildomą išvietę $[18,3]$. Galbūt šią iniciatyvą paskatino poreikis ịrengti atskirą tualetą svečiams ir aptarnaujančiam personalui.

XIX a. pabaigoje tualetai irgi neretai pažymèti atskiroje patalpoje šalia pagalbinių laiptų arba namo bendrojo koridoriaus gale. Tokius matome Alberto Monasevičiaus 382 posesijos namo, kurị apie $1893 \mathrm{~m}$. ịsigijo I. Bunimovičius, $1884 \mathrm{~m}$. plane [10, 3] ir kitame apie 1900 m. I. Bunimovičiaus ịsigytame 296 posesijos namo $1902 \mathrm{~m}$. plane [34, 6v-7], M. Gordono 384 posesijos namo 1890 m. plane [20, 4], pirklių Frank-Kameneckių namo pirmajame aukšte [19, 5v-6], o, pavyzdžiui, Abraomo Parneso name (381 posesijos namas Vokiečių g. tarp Mèsinių ir Žydų g. atkarpoje, neišliko) tualetas ịrengtas koridoriaus gale $[33,14 a]$. Tai buvo ịprastos tualetams ịrengti vietos - atokiau paradinio ịejimo, kad nors kažkiek būtų galima paslèpti šio skleidžiamą kvapą.

Kad pamažu keitėsi tualeto įrangos technologijos ir pačių pirklių požiūris i̇ problemą, netiesiogiai liudija ịvairūs faktai. Aišku, kiekvienas jų yra tik vieno konkretaus žmogaus sprendimas, tačiau šie pavieniai pavyzdžiai leidžia matyti pokyčių visumą.

Antai Mèsinių gatvejje greičiausiai vieno turtingiausių XIX a. vidurio Vilniaus pirklių Judelio Apatovo sūnus vamzdị nešvarumams pašalinti išvedė tiesiog ị miesto griovị $[7,70]$, o 8-9-uoju dešimtmečiais daugelis pirklių renovavo lauko tualetus pagal to meto sanitarinius reikalavimus, kurių būtina sąlyga - įrengta ventiliacija ir moliu išplūkta pamazgų duobẻ. Prašymą renovuoti lauko tualetą 316 posesijos name (buvęs Vokiečių g. 18) 1887 m. padavė Fadiejus Kurkovskis [1346, 9], o 1888 m. cementavo pamazgų duobę ir jos dugną išklojo plytomis [14, 212]; $1881 \mathrm{~m}$. Lazaris Edelšteinas padavè prašymą Lydos skg. 357 posesijos name pastatyti lauko tualetą su pamazgų duobe $[8,54] ; 1888 \mathrm{~m} .312$ posesijos namo (Vokiečių g. 10) savininkas pirklys Davidas Janovas pamazgų duobẻje išvalè užterštą žemę, naujai išplūkè aštuonių varškų moliu, išklojo dugną plytomis ir degutavo medines dèžès sienas $[14,188 v]$. Žinoma, kad pirklys Mauša-Jankelis Parnesas 1901 m. (381 posesija) išviečių valymui per metus išleido $200 \mathrm{rb}$ (šiukšlių ir sniego - $120 \mathrm{rb}$ ) [30, 42v].

Taigi XIX a. pabaigoje buitiniai patogumai pirklių namuose smarkiai pasikeitè, o pirklių Cholemų pavyzdžiu netgi teigtina, kad 10-ajame dešimtmetyje pirklių namuose buvo ịrenginèjami modernūs sanitariniai įrengimai. Klozetai, praustuvai talpinti nebe laiptinèje, kaip anksčiau, bet greta virtuvių, pačiame bute, nors vonias ịrengti daugeliui savininkų vis dar buvo per brangu [61, 137]. Apibendrinant norètųsi pažymėti, kad du paskutinieji XIX a. dešimtmečiai Vilniuje visiškai pagrịstai gali būti laikomi naujų buitinių patogumų formų plitimo laikotarpiu, modernios buities, o kartu ir tipinių butų formavimosi dešimtmečiais.

\section{IŠVADOS}

1. XIX a. viduryje dauguma pirklių stengèsi ịsigyti nuosavus namus miesto centre, kuris buvo patogus ne tik gyventi, bet ir įrengti komercinès paskirties patalpas. Nors senoji miesto teritorijos dalis neprarado komercinio ir administracinio centro vaidmens ir čia liko 
pirkliams priklausančių namų, XIX a. paskutiniais dešimtmečiais vis daugiau pirklių rinkosi modernius naujai plečiamus miesto rajonus: Gedimino pr., Vilniaus, Sodų, Gèlių, Pylimo, J. Basanavičiaus ir kitas Naujamiesčio gatves. Čia jie statėsi nuomojamus namus.

2. Vilniaus pirkliai siekè racionaliai investuoti sukauptas lèšas i nekilnojamąji turtą. Atsisakę nerentabilių, su didelemis išlaikymo sąnaudomis rezidencijų, dauguma jų statèsi nuomojamus namus. Paprastai šių namų pirmieji aukštai būdavo numatyti modernioms, su iš anksto suplanuotais vitrininiais langais parduotuvėms ar kitoms komercinès paskirties įmonėms, o viršutiniai aukštai nuomojami gyventojams. Šių namų vieną, paprastai geriausią, butą užimdavo pats savininkas su šeima.

3. Pirklių būstų išplanavimas neturejo išskirtinių, vien šiam sluoksniui būdingų bruožų. Paprastai pirkliai rinkosi viduriniam sluoksniui skirtus keturių-šešių kambarių butus ir tik labai turtingi miesto pirkliai statèsi didelio ploto rezidencijas.

4. XIX a. viduryje buitiniai patogumai (vandentiekis, tualetas) buvo įrenginèjami kieme. XIX a. 7-uoju dešimtmečiu sanitarinius mazgus pradeda įrenginèti namo viduje. Paprastai jie būdavo bendrojo koridoriaus gale, atokiau centrinio ịejimo. Nors pirklių namuose plito tualetai namo viduje, dar 8-9-uoju dešimtmečiais pirkliai neatsisakè lauko tualetų. Skirtingus patogumus pirklių namuose galèjo lemti ne tik jų materialinès galimybès, bet ir asmeninis požiūris ị higieną, išprusimas, galbūt tam ịtakos turèjo nesandari tualetų sistema, neįrengtas vandentiekis ir nuotakynas.

5. XIX a. pabaigoje mieste atsirado daugiau namų su moderniais patogumais (vonia, „vaterklozetas“, praustuvai, dušai). Šie įrenginiai jau buvo statomi ne bendrojo koridoriaus gale, bet bute, dažniausia patalpoje šalia pagalbinių laiptų. Sanitarinių mazgų ịrengimas bute rodo pirklių gyvenamųjų sąlygų naują komforto lygi. Matyt, neatsitiktinai pirmieji tipiniai butai su voniomis ir klozetais buvo įrengti XIX a. pabaigoje statytuose moderniuose pastatuose. Šių namų butuose atsiranda buržuazinei visuomenei būdingi izoliuoti kambariai.

Gauta 20150928

Priimta 20160111

\section{Šaltiniai}

[1] 1864 Журнал генеральной проверки торговых и промышленных заведений в городе Вильно. Lietuvos valstybés istorijos archyvas (toliau - LVIA), f. 937, ap. 2, b. 336.

[2] 1874 Опись и оценка каменного двухэтажною в части трехэтажного на подвале дома крытого железом и черепицею принадлежащего Виленскому первой гильдии купцу Мейлаху Ниселевичу Кенигсбергу. LVIA, f. 937, ap. 2, b. 4125.

[3] 18751222 Опись и оценка каменного двухэтажною в части на подвалах дома, принадлежащего купцу первой гильдии Мееру Юделевичу и жене его Дине Давидовне Гордонам, состоящего в городе Вильне 5 участка по Сиротской ул. № 26. LVIA, f. 937, ap. 2, b. 3832.

[4] 18760128 Опись и оценка каменного двухэтажною в части на подвалах дома, принадлежащего купцу первой гильдии Мееру Юделевичу и жене его Дине Давидовне Гордонам, состоящего в городе Вильне 5 участка по Сиротской ул. № 1979. LVIA, f. 937, ap. 2, b. 3832.

[5] 18760315 Копия описи и оценка дома двухэтажною на подвале крытого черепицею на Впленской ул. № 720, принадлежащего Гитле Липской. LVIA, f. 937, ap. 2, b. 4128.

[6] 18760531 Опись и оценка одноэтажного в части на подвалах с мезонином дома принадлежащего Вилкомирскому второй гильдии купцу Исааку Берковичу Баку. LVIA, f. 937, ap. 2, b. 4131 . 
[7] 18781031 Донесение Виленскому полицмейстеру о нарушениях удаления отходов. LVIA, f. 938, ap. 4, b. 195.

[8] 1881 Список домовладельцев города Вильны, коим разрешены постройки, переделки и т. п. в период времени с 1 июня по 1 января 1881 года. LVIA, f. 938, ap. 4, b. 527.

[9] 1884 Фасад каменного 2-х этажного дома в 3 участке города Вилны, на Немецкой улице под № 384 Меера Юделиовича Гордона. LVIA, f. 938, ap. 4, b. 839.

[10] 18840907 Проект на надстройку каменного 3-го этажа в доме состоящем в г. Вильне, 3-го участка, по Немецкой и Мясной улице, под № 19 / 382, принадлежащем купцу Альбнрту Юличу Манасевичу. LVIA, f. 938, ap. 4, b. 298.

[11] 1885 Книга для записки торговых предприятий, подлежащих раскладочному сбору по городу Вильно за 1885 год. LVIA, f. 517, ap. 1, b. 1125.

[12] 1885 Список Виленского губернского податного присутствия о раскладке дополнительного сбора с торговых и промышленных предприятий по городу Вильно и Виленскому уезду. LVIA, f. 517, ap. 1, b. 159.

[13] 18870728 Чертеж на постройку каменной лестницы в один этаж, как показано на плане под буквой $a$, и отхожих мест под буквою 5 в доме Ф. Курковского по Немецкой ул., во 2 участке под № 316. LVIA, f. 938, ap. 4, b. 1346.

[14] 1888 Список домовладельцам г. Вильны, коим по постановлениям Городской Управы разрешены постройки и капитальные переделки, строений в период времени с 1 января 1887 г. по 1 января 1888 г. LVIA, f. 938, ap. 4, b. 1281.

[15] 1888 Формулярный список о службе Виленского торгового депутата, первой гильдии купца Гордона. Российский государственньй исторический архив в Санкт Петербурге, ф. 20, оп. 2, д. 729.

[16] 18880611 Чертеж предполагаемой пристройки, к существующему каменному 2-х этажному дому принадлежащему 1-ой гильдии купцу Мееру Юделевичу и жене его Дине Давидовне Гордонам в г. Вильне на Сиротской улице в 5-м участке под № 26. LVIA, f.938, ap. 8, b. 1610 .

[17] 1889 Книга торговых предприятий подлежащих раскладочному сбору по городу Вильно и его уезду. LVIA, f. 517, ap. 1, b. 1128.

[18] 1889 Копия проекта на постройку каменных холодных служб во дворе дома принадл. Јосифу Станиславовичу Монтвиллу по Георгиевскому проспекту в 4-м полицейском участке г. Вильны под № 857. LVIA, f. 938, ap. 4, b. 1888.

[19] 18900116 Проект надстройки 3-его этажа над существующим двух-этажным с погребом домом с пристройкою лит. В, показ. на плане местности, принадл. Гершону и Теме Франк-Каменецким в г. Вильне на углу улицы Стеклянной и Дворцового переулка в 3-м полицейском под № 217/12. LVIA, f. 938, ap. 4, b. 1955.

[20] 18900703 Копия чертежа на надстройку третьего этажа на существующем двухэтажном каменном доме и постройку двух несгораемых в три этажа лестниц в 3 участке города Вильны по Немецкой улице под номером 384 Мееру Юделевичу Гордону принадлежащем. LVIA, f. 938, ap. 4, b. 2065.

[21] 1891 Список домовладельцам г. Вильны, коим по постановлению Государственной управы разрешены постройки и капитальные переделки строений в период времени с 1 января 1890 г. по с 1 января 1891 г. LVIA, f. 938, ap. 4, b. 1969.

[22] 1893 Копия чертежа реконструкции углового дома № 382 (19) по Немецкой и Мясной улицам. $L V I A$, f. 938 , ap. 4, b. 2456.

[23] 1894 Книга гильдейских торговых предприятий подлежащих раскладочному сбору по 
г. Вильна и его уезду. LVIA, f. 515, ap. 9, b. 1182.

[24] 1894 Список домовладельцам г. Вильны, коим по постановлению Государственной управы разрешены постройки и капитальные переделки строений в период времени с 1 января 1893 г. по с 1 января 1894 г. LVIA, f. 938, ap. 4, b. 2409.

[25] 18950528 Копия проекта надстройки 4-го этажа на существующем 3-х этажном дом и пробивки окон и дверей по фасаду в доме Лейбы и Ривки Залкинд на углу Большой и Милионной ул. под № 13/3 1-го участка города Вильны с показанием предполагаемой пристройки во дворе. LVIA, f. 938, ap. 4, b. 2730.

[26] 1897 Книга гильдейских торговых предприятий подлежащих раскладочному сбору по гор. Вильни и его уезду. LVIA, f. 515, ap. 9, b. 1281.

[27] 1898 Книга гильдейских торговых предприятий, подлежащих раскладочному сбору по городу Вильно и его уезду. LVIA, f. 515, ap. 9, b. 1295.

[28] 18980918 Копия чертежа на постройку 3-х этажного на подвалах дома в 1 участке гор. Вильны при Архангельской улице, братьев Холем. LVIA, f. 938, ap. 4, b. 3221.

[29] 1901 Ведомость Виленской городской оценочной комиссии домов по Немецкой улицы. LVIA, f. 938, ap. 8, b. 277.

[30] 1901 Ведомость Виленской городской оценочной комиссии домов по Немецкой улицы. LVIA, f. 938 , ap. 8, b. 278.

[31] 19011220 Заявление Санкт Петербургского 1-ой гильдии купца Израиля Беньяминовича Бунимовмча в оценочную комиссию при Виленской Городской Управе. LVIA, f. 938, ap. 8, b. 278.

[32] 1902 Прошения Виленских купцов о выдаче метрических выпеснй о составе семьи. LVIA, f. 938, ap. 10, b. 121, 1. 629.

[33] 19020410 План части 3-х этажного каменного дома существующего в 3-м участке г. Вильны при Немецкой улице под № 381 в владении купца Якова Абрамовича Парнеса с показанием устройства деревянной винтовой лестницы для соеденинения магазина 1 этажа с квартирой 2-го этажа. LVIA, f. 938, ap. 4, b. 3348.

[34] 19020708 Дополнительный проект на капитальную переделку существующего каменного 2-го этажа с частью 3-х этажного с небольшим погребом дома и переделку окон и дверей в 1-м этаже с улицы в оном доме под лит. А принадлеж. купцу И. Б. Бунимовичу, состоящем во 2-м участке города Вильны при Рудницкой и Немецкой улице. LVIA, f. 938, ap. 4, b. 3511.

[35] Reklaminis skelbimas. Северо-Западное слово, 13 апреля 1899 г.

[36] Reklaminis skelbimas. Северо-западное слово, 1 мая 1899 г.

[37] Reklaminis skelbimas. Северо-западное слово, 10 сентября 1899 г.

[38] Reklaminis skelbimas. Северо-западное слово, 16 сентября 1899 г.

[39] Reklaminis skelbimas. Северо-западное слово, 22 апреля 1900 г.

[40] Reklaminis skelbimas. Северо-западное слово, 8 ноября 1900 г.

[41] Reklaminis skelbimas. Северо-западное слово, 15 апреля 1901 г.

[42] Reklaminis skelbimas. Северо-западное слово, 12 декабря 1901 г.

[43] Reklaminis skelbimas. Северо-Западное слово, 17 апреля 1904 г.

[44] Reklaminis skelbimas. Северо-Западное слово, 28 августа 1904 г.

[45] Reklaminis skelbimas. Северо-западное слово, 12 сентября 1904 г.

[46] Reklaminis skelbimas. Северо-западное слово, 26 марта 1905 г.

[47] Адресная книга учреждений и должностных лиц г. Вильны. Вилна, 1903.

[48] В Вильне. Бедный город (перепечатано из Przegląd Wileński). Вечерняя газета, 18 июня 1913 г., № 267.

[49] Залькинд, В.С. Опыт медико-типографического описания Вильны. Отрывокдокторской 
диссертации, 1891. Памятная книжка Виленской губернии, 1892.

[50] М. М-ля. Санитарное состояние Вильны. Вильна, 1892.

[51] Указатель города Вильны. Составлен по распоряжению господина главного начальника края. Вильна, 1864.

\section{Literatūra}

[52] AMBRULEVIČIŪTĖ, Aelita. Vilniaus pirkliai žydai 1801-1861 m. (sąrašas). Vilnius, 2012.

[53] BERMAN, Leslie Susan. The Evolution of the Nineteenth-Century American Dining Room: From Sitting Room to Separate Room. University of Pennsylvania, 1997.

[54] DAUNTON, Martin. House and Home: Working-class Housing in the Victorian City, 18501914. London, 1984.

[55] FOY, Jessica H.; SCHLERETH, Thomas J. American Home Life, 1880-1930: A Social History of Spaces and Service. University of Tennessee Press, 1994.

[56] FRYKMAN, John; LÖFGREN, Orvar. Culture Builders: A Historical Anthropology of MiddleClass Life. London: New Brunswick, 1990.

[57] GELERNTER, Mark. A History of American Architecture: Buildings in Their Cultural and Technological Context. Manchester University Press, 2001.

[58] HALLIDAY, Stephen. The Great Stink of London: Sir Joseph Bazalgette and Cleansing of the Victorian Metropolis. History Press, 1999.

[59] JURGINIS, Juozas; MERKYS, Vytautas; TAUTAVIČIUS, Adolfas. Vilniaus miesto istorija nuo seniausiuju laiku iki Spalio revoliucijos. Vilnius, 1968.

[60] Lietuvos architektūros istorija. Nuo XIX a. II dešimtmečio iki 1918 m. T. III. Vilnius, 2000.

[61] LUKŠIONYTĖ-TOLVAIŠIENĖ, Nijolè. Istorizmas ir modernas Vilniaus architektūroje. Acta Academiae artium Vilnensis. Dailè. Vilnius, 2000, Nr. 18.

[62] MILlER, Ury. "The Family Is Not Rich But They've Got Integrity", or A Few Leaves From The Genealogical Tree. Prieiga per internetą: <the-ratner-family.com/Family_story.eng.htm> [žiūrèta $20150416]$.

[63] TIMOTHY, J. Bungum. The Contributions of Two Public Health Pioneers: John Snow and Joseph Goldberger. Nevada Journal of Public Health, 2005, Vol. 2(1), p. 14-19.

[64] VRIES de, Jan. The Industrious Revolution. Consumer Behavior and the Household Economy, 1650 to the Present Day. University of California at Berkley: Cambridge University Press, 2008.

[65] АГРАНОВСКИЙ, Генрих; ГУЗЕНБЕРГ, Ирина. Вильнюс: по следам титовского Иерусалима. Вильнюс, 2011.

[66] БОГДАНОВ, Игорь. Unitas или краткая история туалета. Сантк Петербург, 2007.

[67] ПУНИН, Андрей. Л. Архитектура Петербурга середины ХІХ века. Prieiga per internetą: <http://mypiter.name/wiki/Доходные+дома/> [žiūrèta 201509 07].

[68] СИЛЬГИ де, Катрин. История мусора от средних веков до наших дней. Москва, 2011.

[69] ХАРИСЕЕВА, Наталия. Московское купечество на рубеже ХІХ-ХХ веков: соииокультурный анализ. Автореф. дис. на соиск. учен. степ. канд. культурологии. специальность 24.00.01 „Теория и история культуры“, 2009. 


\section{Changes of household in Vilnius merchants' houses in the second half of 19 th century}

Summary

Towards the end of 19th century, the living conditions of Vilnius residents had changed significantly. Already in the middle of 19th century, many merchants sought to purchase their own properties in the city centre, as it was convenient not only to live there but also to establish commercial premises. Through the last decades of the 19th century, more merchants chose to relocate to the new, expanding and modern districts, where they built apartment buildings as rental properties. The landlord family would occupy one of the apartments. Only very wealthy Vilnius merchants were able to afford the construction of large residences.

The merchants' dwellings did not possess any unique design features, which could be appointed predominantly to this social group. Usually, the merchants chose to live in the typical middle class apartments with 4-6 rooms, with characterised rooms (drawing room, bedroom, study room, etc.).

The household amenities such as water supply and toilet in the middle of 19th century were mostly erected in the backyards. Although, from the seventh decade of 19th century, sanitary facilities started to be gradually installed inside the house, but even throughout the eighth and ninth decades, many merchants still kept their outside toilets. Such disparity in the sanitary conditions amongst the merchants could have been influenced not only by their financial potentials but also by their personal approach to hygiene or the lack of water supply and sewerage systems, and the faulty toilet equipment. By the end of 19th century, more homes became equipped with modern amenities (bath tube, water closet, wash basins, showers). These amenities were installed inside the apartments. This indicated the rise of merchants' living conditions to a higher comfort level.

Keys words: XIX century, Vilnius, merchants, home comfort 